\title{
Short-Term Response of Young Mandarin Trees to Desalinated Seawater Irrigation
}

\author{
Jose F. Maestre-Valero ${ }^{1, *}$, Victoriano Martínez-Alvarez ${ }^{1} \mathbb{D}$, Francisco J. Jódar-Conesa ${ }^{1}$, \\ Jose A. Acosta ${ }^{1}$, Bernardo Martin-Gorriz ${ }^{1} \mathbb{D}$, Juan M. Robles ${ }^{2}$, Juan G. Pérez-Pérez ${ }^{2,3} \mathbb{I D}^{\text {and }}$ \\ Josefa M. Navarro ${ }^{2}$ \\ 1 Agricultural Engineering Center, Technical University of Cartagena, Paseo Alfonso XIII 48, \\ 30203 Cartagena, Spain; victoriano.martinez@upct.es (V.M.-A.); franconesa@live.com (F.J.J.-C.); \\ ja.acosta@upct.es (J.A.A.); b.martin@upct.es (B.M.-G.) \\ 2 Equipo de Riego y Fisiología del Estrés, Departamento de Bioeconomía, Agua y Medio Ambiente, Instituto \\ Murciano de Investigación y Desarrollo Agrario y Alimentario (IMIDA), c/Mayor s/n, \\ 30150 La Alberca, Murcia, Spain; juanmiguelrobles@gmail.com (J.M.R.); perez_juaperb@gva.es (J.G.P.-P.); \\ josefam.navarro2@carm.es (J.M.N.) \\ 3 Centro para el Desarrollo de la Agricultura Sostenible, Instituto Valenciano de Investigaciones \\ Agrarias (IVIA), Crta. CV-315 km 10.7, 46113 Moncada, Valencia, Spain \\ * Correspondence: josef.maestre@upct.es; Tel.: +34-968-325-658
}

Received: 10 December 2019; Accepted: 28 December 2019; Published: 4 January 2020

\begin{abstract}
Water deficit and increasing pressure on water resources in semi-arid regions has led to the spread of irrigation with non-conventional water resources, such as desalinated seawater (DSW). The few existent studies to date, mainly carried out in Israel and Spain, have shown that suitable management of irrigation with DSW must be performed to avoid agronomic problems and reductions in crop productivity and fruit quality in the mid-long term. To the best of our knowledge, in the case of citrus, fruit production, and quality, information on the effects of DSW irrigation is not available. In this study, we evaluated the short-term agronomic and economic effects of irrigating a mandarin orchard during two crop cycles (2017-2019) with (i) fresh water (FW), (ii) desalinated seawater (DSW), and (iii) a mix of water composed of $50 \% \mathrm{FW}$ and $50 \%$ DSW. Stem water potential $\left(\Psi_{\mathrm{S}}<-1 \mathrm{MPa}\right)$ and gas exchange parameters (net photosynthesis; $\mathrm{A}>6.5 \mu \mathrm{mol} / \mathrm{m}^{2} / \mathrm{s}$ and stomatal conductance; $\mathrm{g}_{\mathrm{s}}>$ $65 \mathrm{mmol} / \mathrm{m}^{2} / \mathrm{s}$ ) indicated that trees were well irrigated throughout the experiment. The concentration of $\mathrm{Na}^{+}$and $\mathrm{B}^{3+}$ in the DSW always exceeded the maximum thresholds for irrigation water proposed in the literature for citrus, and the concentration of $\mathrm{Na}^{+}$in the leaves exceeded the maximum threshold in summer 2018. Nonetheless, symptoms of toxicity were not observed. Significant differences among treatments were not observed for $\Psi_{\text {stem }}, \mathrm{A}, \mathrm{g}_{\mathrm{s}}, \mathrm{Na}^{+}, \mathrm{Cl}^{-}$, and $\mathrm{B}^{3+}$ in leaves (except in the summer months), yield components, fruit quality, or the economic assessment. The lack of such differences was explained by the large standard deviations caused by the youth of the trees, with figures that on occasion could represent more than $100 \%$ of the mean value. These results may justify the agronomic and economic viability of the irrigation of young trees with DSW in the short-term, but further research, considering the effects on adult trees in the long term is still needed.
\end{abstract}

Keywords: phytotoxicity; food security; non-conventional water resources; water productivity; economic assessment

\section{Introduction}

Feeding nine billion people in 2050 will require increasing world food production by $70-100 \%$, which will only be possible under intensive irrigated agriculture [1]. However, in arid and semiarid regions, freshwater availability is being reduced by climate change, which creates imbalances 
between renewable resources and total demands and jeopardizes the sustainability of irrigated agriculture, its resilience, and hence food production [2]. A clear example is the Segura River Basin (SRB), an irrigation area of 262,400 ha located in southeastern Spain, which supports an annual structural water deficit above $400 \mathrm{hm}^{3}$; i.e., $1524 \mathrm{~m}^{3} /$ ha [3]. In this hydrologically stressed region, the compulsory allocation of water creates significant conflicts among aggravated users, with farmers being especially affected during drought periods. In order to redress this limitation of conventional water resource availability, and to continue providing society with food, farmers complement their share of conventional water resources with other non-conventional resources, such as desalinated seawater (DSW) [4].

The DSW represents an abundant and steady coastal water source, which effectively removes the climatological and hydrological constraints. In the SRB, $184.3 \mathrm{hm}^{3}$ of DSW is annually used for irrigation representing $74 \%$ of the total production of DSW in the basin and $11.9 \%$ of its agricultural demand [5].

Limited fundamental scientific researches evaluated the agronomic, economic, environmental, social, and policy implications of DSW irrigation in agriculture. As positive aspects, studies state that (i) it may provide drought risk-buffering value [4]; (ii) its low salinity can produce significant increases in the quality and quantity of crop yields, especially when replacing low quality water supplies in water stressed regions [6]; (iii) it may reverse previous problematic trends of soil salinization attributed to irrigation with poor-quality water, and provide a path to sustainable irrigated agriculture in arid and semiarid environments [5]; and (iv) the replacement of traditional water sources with DSW represents new water policies and water management options $[7,8]$. On the contrary, DSW produced through reverse osmosis $(\mathrm{RO})$ does not seem to be problem free, especially when compared with other conventional water resources. The main significant limitations are: (i) the lack of plant nutrients [9]; (ii) the compliance of stringent $\mathrm{B}^{3+}, \mathrm{Na}^{+}$, and $\mathrm{Cl}^{-}$standards for agricultural irrigation, especially for sensitive crops; i.e., most woody crops [10]; (iii) the effects of $\mathrm{Na}^{+}$accumulation in soil structure and productivity [11]; (iv) the energy requirements and resulting costs [12]; (v) the high emission of greenhouse gases that further exacerbates climate change [13]; and (vi) the impacts of massive brine disposal on oceanic life [14]. Despite these references, the agronomic issues associated to irrigation with DSW have been poorly evaluated. Some of the existent results, mainly obtained in Israel and Spain, can be consulted in Maestre-Valero et al. and Martinez-Alvarez et al. [15,16]. Consequently, studies dealing with the analysis of the effects of irrigation with DSW on crops and soils are necessary to bring down barriers and improve the farmers' perceptions and acceptance of DSW, which might, in turn, condition its sustainable use [8].

In this sense, a young mandarin tree orchard was irrigated with DSW for two consecutive seasons and the main agronomic implications, providing special reference to the effects on tree water relations, leaf mineral concentrations, vegetative growth, gas exchange parameters, soil salinity and sodicity, and fruit yield and quality were evaluated. A simple economic assessment of the irrigation with DSW was also performed.

\section{Material and Methods}

\subsection{Experimental Plot and Irrigation Treatments}

The experiment began in October 2017 and was carried out for 21 months at a commercial mandarin orchard located in Torre Pacheco, Murcia, Spain ( $37^{\circ} 47^{\prime} 30^{\prime \prime} \mathrm{N} ; 1^{\circ} 03^{\prime} 85^{\prime \prime} \mathrm{W} ; 30 \mathrm{~m}$ above sea level). The experiment finished by mid-June 2019 and covered two crop cycles.

This area is characterized by a Mediterranean semi-arid climate with warm, dry summers and mild winter conditions. The average annual reference evapotranspiration $\left(\mathrm{ET}_{0}\right)$ and rainfall are $1326 \mathrm{~mm}$ and $300 \mathrm{~mm}$, respectively.

The experimental plot consisted of 0.5 ha cultivated with 3-year old (in 2017) mandarin trees (cv. Safor) grafted on Macrophylla rootstock (Citrus Macrophylla) with a tree spacing of $5 \mathrm{~m} \times 3 \mathrm{~m}$. 
The soil had a loamy sandy texture (20\% clay, $20 \%$ loam, and $60 \%$ sand) within the first $50 \mathrm{~cm}$ depth, with an average bulk density of $1.3 \mathrm{~g} / \mathrm{cm}^{3}$. The soil electrical conductivity $\left(\mathrm{EC}_{\mathrm{e}}\right)$ before the experiment showed large variability, ranging between 4.4 and $8.4 \mathrm{dS} / \mathrm{m}$ and the sodium adsortium ratio $\left(\mathrm{SAR}_{\mathrm{e}}\right)$ between 2.9 and $3.9[\mathrm{mmol} / \mathrm{L}]^{0.5}$.

The experiment was laid out as a randomized complete design with four blocks and three experimental plots per block. The standard plot, which covered about $180 \mathrm{~m}^{2}$ was made up of twelve trees, organized in three adjacent rows with four trees per row. The two central trees of the middle row were used for measurements, with the other ten trees being guard trees.

\subsection{Irrigation System, Management and Treatments}

The irrigation system consisted of a single drip line laid on the soil surface next to each tree row. Two self-pressure compensating on-line emitters per tree provided a discharge of $4 \mathrm{~L} / \mathrm{h}$ each. Emitters were placed at $0.50 \mathrm{~m}$ from the trunk and spaced $0.75 \mathrm{~m}$ apart. The irrigation doses were scheduled on the basis of the daily crop evapotranspiration $\left(\mathrm{ET}_{\mathrm{c}}\right)$ accumulated during the previous week. The daily $\mathrm{ET}_{\mathrm{c}}$ values were estimated by multiplying the daily reference evapotranspiration $\left(\mathrm{ET}_{0}\right)$, calculated with the Penman-Monteith methodology [17], by the month-specific crop coefficients for citrus provided by Castel et al. [18]. In addition, a reduction coefficient $\left(\mathrm{K}_{\mathrm{r}}=0.22\right)$, which accounted for an eventual decrease in evapotranspiration because of the partial soil covering by the crop canopy (young mandarin trees), was used [19]. The meteorological data to calculate $\mathrm{ET}_{0}$ were collected from the nearest automatic weather station (TP-91) belonging to the Sistema de Información Agraria de Murcia. Additionally, two soil water content probes (HydraProbe II-Stevenswater, Portland, OR, USA) per plot were installed at $25 \mathrm{~cm}$ and $50 \mathrm{~cm}$ depths and connected to an automatic datalogger CR1000 (Campbell Scientific, Logan, UT, USA) to continuously monitor soil moisture and check that the trees did not suffer water stress during the experiment. No leaching fraction was added to the irrigation doses regardless of water salinity.

The irrigation control head of the entire experimental area was equipped with pumps, a fertigation system, electrovalves, an automatic irrigation programmer, and filters. All the treatments received the same amounts of fertilizer $\left(\mathrm{N}-\mathrm{P}_{2} \mathrm{O}_{5}-\mathrm{K}_{2} \mathrm{O}\right)$, applied through the drip irrigation system (174-98-220 $\mathrm{kg} / \mathrm{ha} /$ year from Oct-2017 to Sept-2018 and 110-35-98 kg/ha/year from Oct-2018 to Jun-2019), irrespective of the water quality. Pest control practices and pruning were those commonly used by growers in the area, and no weeds were allowed to develop within the orchard.

The treatments were established by supplying three water sources to the irrigation system; the first source $(\mathrm{FW})$, with an average electrical conductivity $\left(\mathrm{EC}_{\mathrm{W}}\right)$ of $1.40 \pm 0.30 \mathrm{dS} / \mathrm{m}$, was provided by the Campo de Cartagena irrigator's community. The second source (DSW) was obtained from the desalination plant of Escombreras $\left(\mathrm{EC}_{\mathrm{W}}=0.91 \pm 0.10 \mathrm{dS} / \mathrm{m}\right)$. The third treatment $(\mathrm{MW})$ was a mix of water composed of $50 \% \mathrm{FW}$ and $50 \% \mathrm{DSW}\left(\mathrm{EC}_{\mathrm{w}}=1.19 \pm 0.30 \mathrm{dS} / \mathrm{m}\right)$.

\subsection{Irrigation Water Quality}

One water sample from each water source was collected in glass bottles, transported in an ice chest to the laboratory and stored at $5{ }^{\circ} \mathrm{C}$ before being processed for physical and chemical analyses. Water samplings were performed on a monthly basis throughout the experiment. An inductively coupled plasma (ICP-MS Agilent Technologies, Model 7900, Santa Calara, CA, USA) was used to determine the concentration of $\mathrm{Na}^{+}, \mathrm{K}+, \mathrm{Ca}^{2+}, \mathrm{Mg}^{2+}$, and $\mathrm{B}^{3+}$. Anions $\left(\mathrm{Cl}^{-}, \mathrm{NO}_{3}{ }^{-}, \mathrm{PO}_{4}{ }^{3-}\right.$, and $\left.\mathrm{SO}_{4}{ }^{2-}\right)$ were quantified by ion chromatography with a liquid chromatograph (Thermo Scientific Dionex, Model ICS-2100, Thermo Scientific, Basel, Switzerland). The EC $\mathrm{w}_{\mathrm{w}}$ was determined using a conductivity instrument GLP-31 (Crison Instruments S.A., Barcelona, Spain); $\mathrm{pH}$ was measured with a $\mathrm{pH}$-meter GLP-21 (Crison Instruments S.A., Barcelona, Spain). The sodium adsorption ratio $\left(\mathrm{SAR}_{\mathrm{w}}\right)$ was also calculated from the concentration of $\mathrm{Na}^{+}, \mathrm{Ca}^{2+}$, and $\mathrm{Mg}^{2+}$ measured in the irrigation water. 


\subsection{Soil Characterization}

The area surrounding one central tree in each replicate was selected to collect data for the analyses. Three soil samples were collected per replicate four times per year at $0-25 \mathrm{~cm}$ and $25-50 \mathrm{~cm}$ depths and $0.30 \mathrm{~m}$ away from the emitter. A total of 144 samples were collected during the experiment. Soluble salt contents were determined in the saturated paste extract as described by Rhoades [20]. The electrical conductivity of the saturated paste extract $\left(\mathrm{EC}_{\mathrm{e}}\right)$ was measured with a conductivity GLP-31 meter (Crison Instruments, Barcelona, Spain). An inductively coupled plasma (ICP-MS Agilent Technologies, Model 7900, Santa Calara, CA, USA) was used to determine the concentration of water soluble $\mathrm{Na}^{+}$, $\mathrm{Ca}^{2+}$, and $\mathrm{Mg}^{2+}$. The sodium adsorption ratio $\left(\mathrm{SAR}_{\mathrm{e}}\right)$ was also calculated from the concentration of $\mathrm{Na}^{+}, \mathrm{Ca}^{2+}$, and $\mathrm{Mg}^{2+}$ measured in the saturated paste extract. The sodicity risk due to the irrigation water quality was analyzed based on the relation of the $\mathrm{SAR}_{\mathrm{w}}$ and the $\mathrm{EC}_{\mathrm{w}}$. Extractable $\mathrm{B}^{3+}$ was determined in soil samples by refluxing $20 \mathrm{~g}$ soil with $40 \mathrm{~mL}$ hot water (boiling) for a period of $5 \mathrm{~min}$. One aliquot from the filtered extract was then used for measuring $\mathrm{B}^{3+}$ using an inductively coupled plasma (ICP-MS Agilent Technologies, Model 7900, Santa Calara, CA, USA).

\subsection{Determinations in Plants}

\subsubsection{Vegetative Growth}

Before the beginning of the experiment, all trees' canopy height and perimeter and trunk perimeter were measured. Vegetative growth (canopy perimeter and diameter) was also measured at the end of each season after the harvest. The canopy equatorial area was calculated from the perimeter of the tree's foliage, measured with ranging rods.

\subsubsection{Leaf Water Relations}

Mid-day stem water potential" is known as the best leaf-based physiological response indicator for recording moisture status of the citrus tree. From May 2018, monthly measurements of stem water potential $\left(\Psi_{\text {stem }}\right)$ were performed at solar noon (12:00 h Greenwich Mean Time), using a Scholander-type pressure chamber (model 3000; Soil Moisture Equipment Corp., Santa Barbara, CA, USA) and following Turner [21] recommendations. Two mature, fully expanded leaves and close to the trunk were taken from the two central trees of each replicate. Before the collection and measurement, the leaves were enclosed within polyethylene bags covered with aluminum foil, at least $2 \mathrm{~h}$ prior to the measurement [22].

On the same dates, a leaf from the same shoot was used to measure the leaf water potential ( $\left.\Psi_{\text {leaf }}\right)$. The $\Psi_{\text {leaf }}$ was also measured at midday using the pressure chamber. Following $\Psi_{\text {leaf }}$ measurement, the leaves were immediately frozen and stored at $-80^{\circ} \mathrm{C}$ for determination of leaf osmotic potential $\left(\Psi_{\text {osm }}\right)$ by a Wescor 5520 vapor pressure osmometer. Leaf turgor potential was calculated as the difference between $\Psi_{\text {leaf }}$ and $\Psi_{\text {osm }}$.

\subsubsection{Leaf Analysis}

To perform the analyses, leaves from non-fruiting twigs located in the central part of the tree were sampled monthly for each of the seasons. Ten leaves per tree were sampled in the two central trees of each replicate. Adhered soil and dust particles were removed from leaf samples by washing with deionized water and freeze-drying. Dried leaves were ground and digested in a microwave digestion system (Cem Corporation, Matthews, NC, USA) with a mix of hydrochloric acid $(0.5 \mathrm{~mL})$ (Suprapur, Merk), nitric acid (9 mL) (Suprapur, Merk), and hydrogen peroxide (1 mL) (Sigma Aldrich, San Luis, MO, USA) (USEPA-3052). Leaf macronutrients $\left(\mathrm{P}, \mathrm{K}^{+}, \mathrm{Ca}^{2+}\right.$ and $\left.\mathrm{Mg}^{2+}\right)$, micronutrients $(\mathrm{Fe}, \mathrm{Mn}$ and $\mathrm{Zn})$ and phytotoxic elements $\left(\mathrm{Na}^{+}\right.$and $\left.\mathrm{B}^{3+}\right)$ were determined by inductively coupled plasma mass spectrometry (ICP-MS Agilent Technologies, Model 7900, Santa Calara, CA, USA). Chlorides were extracted from $0.5 \mathrm{~g}$ of ground leaves with $25 \mathrm{~mL}$ deionized water and measured by ion chromatography with a liquid chromatograph (Thermo Scientific Dionex, Model ICS-2100, 
Switzerland). Nitrogen was determined by the Kjeldahl method [23]. Additionally, proline was extracted from $50 \mathrm{mg}$ of freeze-dried leaves with sulphosalicylic acid (3\%) and quantified according to the protocol described by Bates et al. [24] and modified by Torrecillas et al. [25].

\subsubsection{Gas Exchange Parameters}

Gas exchange was measured between 09:00 and 11:00 h on a weekly basis from May 2018 to May 2019 on selected clear days. Measurements were made on healthy, fully expanded mature leaves (one leaf on each of the six trees per treatment), exposed to the sun, from young branches in exterior mid-canopy positions. The net $\mathrm{CO}_{2}$ assimilation rate $(\mathrm{A})$, stomatal conductance to water vapor $\left(\mathrm{g}_{\mathrm{s}}\right)$ and transpiration rate (E) were measured with a portable photosynthesis system (LI-6400, Li-Cor, Lincoln, NE, USA) equipped with a broadleaf chamber $\left(6.0 \mathrm{~cm}^{2}\right)$. The leaf chamber temperature was maintained between 28 and $32{ }^{\circ} \mathrm{C}$, leaf to air vapor pressure deficit at $2.5 \pm 0.5 \mathrm{kPa}$ and the relative humidity of the chamber at $30-40 \%$ during measurements. The molar air flow rate inside the leaf chamber was $500 \mu \mathrm{mol} \mathrm{mol}^{-1}$. Portable 12-g cartridges of high-pressure, liquefied, pure $\mathrm{CO}_{2}$ were attached to the console by an external $\mathrm{CO}_{2}$ source assembly and were controlled automatically by a $\mathrm{CO}_{2}$ injector system (6400-01 Li-Cor, Lincoln, NE, USA). All measurements were taken at a reference $\mathrm{CO}_{2}$ concentration similar to ambient $\left(400 \mu \mathrm{mol} \mathrm{mol}^{-1}\right)$ and a saturating photosynthetic photon flux of $1200 \mu \mathrm{mol} \mathrm{m}{ }^{-2} \mathrm{~s}^{-1}[26,27]$, using a red/blue light source (6400-02B LED, LI-COR, Lincoln, NE, USA) attached to the leaf chamber. Gas exchange parameters were calculated automatically by the internal program of the LI-6400, based on the equations of von Caemmerer and Farquhar [28].

\subsubsection{Yield and Fruit Quality}

In February 2018 and 2019, six inner trees per treatment; i.e., two per replicate, were evaluated to determine (i) number of fruits per tree, (ii) yield in total kilograms per tree, and (iii) fruit weight. As the trees were young, only one pick was necessary at each harvest period to collect all the mandarins. Each season, 54 fruits per treatment (18 fruits per block) were randomly selected to study the fruit quality. In 2018, the fruits were cut in the equatorial area and the juice content (JC) and soluble solid content (SSC) were determined. To do so, the fruits were squeezed and the juice filtered and weighted. The SSC of the juice was measured at $25^{\circ} \mathrm{C}$ with a digital refractometer (Atago, Palette PR100). In 2019, in addition to these measurements, the equatorial and longitudinal diameters were determined and the fruit fractions, juice, peel, and pulp, were separated, weighed, and expressed as percentages; the peel thickness was measured at three points with a digital caliper; the tritratable acidity (TA) (expressed as percentage of citric acid in the juice) was determined by titration with $0.1 \mathrm{~N} \mathrm{NaOH}$ to $\mathrm{pH} 8.1$, using an automatic titrator (CRISON Titro-Matic 2S, Crison Instruments S.A., Barcelona, Spain); and the maturity index (MI) was expressed as the SSC $\times 10 /$ TA ratio.

\subsubsection{Economic Assessment}

A simple economic analysis was performed. It should be noted that this only considered the economic return calculated each season for the yield and the prices received by growers for selling the fruit $(0.4 € / \mathrm{kg})$ as income, and the use of water and its cost under each scenario; i.e., $\mathrm{FW}=0.35 € / \mathrm{m}^{3}$, $\mathrm{DSW}=0.60 € / \mathrm{m}^{3}$, and $\mathrm{MW}=0.47 € / \mathrm{m}^{3}$ as outlay.

\subsection{Statistical Analysis}

Statistical analysis was performed as a weighted analysis of variance (ANOVA; statistical software IBM SPSS Statistics v. 21 for Windows). The Shapiro-Wilk test $(\mathrm{P}<0.05)$ was used to evaluate the normality of the data. Tukey's Honestly Significant Difference (HSD) test $(\mathrm{P} \leq 0.05)$ was used for mean separation. Unless otherwise stated, the significance level was $\mathrm{P} \leq 0.05$. 


\section{Results and Discussion}

\subsection{Irrigation Water Quality and Volume Applied}

The water quality parameters for the FW, DSW, and MW are shown in Table 1. Notable differences between the FW and DSW were observed throughout the experiment. Reverse osmosis membranes do not only separate the undesirable salts from the water, but also remove minerals that are essential nutrients for plant growth [29]; especially divalent ions such as $\mathrm{Ca}^{2+}, \mathrm{Mg}^{2+}$, and $\mathrm{SO}_{4}{ }^{2-}$ with higher molecular mass. In this sense, $\mathrm{Ca}^{2+}, \mathrm{Mg}^{2+}$, and $\mathrm{SO}_{4}{ }^{2-}$ in the DSW were only $37.3 \%, 20.4 \%$, and $8.0 \%$ of those measured in the FW from Oct-2017 to Sept-2018 and 50.9\%, 33.7\%, and 21.6\% of those measured in the FW from Oct-2018 to June-2019. However, the concentrations of $\mathrm{Na}^{+}$and $\mathrm{Cl}^{-}$, in the DSW were still high and similar to those found in the FW (Table 1). In the case of $\mathrm{Na}^{+}$and $\mathrm{Cl}^{-}$, the selectivity of the one-stage RO process is high; $99.81 \%$ and $98.93 \%$, respectively. However, both ions represent the largest part of the salts in marine water; $10.8 \mathrm{~g} / \mathrm{L}$ and $19.5 \mathrm{~g} / \mathrm{L}(30.2 \%$ and $54.3 \%$, respectively), which explains their high concentrations in the DSW. The boron concentration in the DSW was similar to that found in the FW, a circumstance that was attributed to the low selectivity for $\mathrm{B}^{3+}$ of the one-stage $\mathrm{RO}$ process $(71.11 \%)$ due to its low molecular mass $(10.811 \mathrm{~g} / \mathrm{mol})$, which hinders its retention by the RO membranes. Additionally, in Spain, no legal regulation exists to condition the quality of the DSW devoted for irrigation, but its production is regulated by the Royal Decree 140/2003, which establishes the sanitary criteria for the quality of DSW for human consumption and the maximum $\mathrm{B}^{3+}$ concentration at $1 \mathrm{mg} / \mathrm{L}$. It is of note that $\mathrm{Na}^{+}$and $\mathrm{B}^{3+}$ concentrations surpassed the maximum published threshold for citrus irrigation $[4,30,31]$ and hence, detrimental effects on crops might occur (Table 1 ).

Table 1. Chemical properties (electrical conductivity: $\mathrm{EC}_{\mathrm{w}}$, Sodium adsorptium ratio: $\mathrm{SAR}_{\mathrm{w}}, \mathrm{pH}$, cations: $\mathrm{Na}^{+}, \mathrm{K}^{+}, \mathrm{Ca}^{2+}, \mathrm{Mg}^{2+}, \mathrm{B}^{3+}$ and anions: $\mathrm{Cl}^{-}, \mathrm{NO}_{3}{ }^{-}, \mathrm{PO}_{4}{ }^{3-}$, and $\mathrm{SO}_{4}{ }^{2-}$ ) for fresh water (FW), desalinated seawater (DSW), and mixed water (MW). Data are divided into the two main periods of the study.

\begin{tabular}{|c|c|c|c|c|c|c|c|}
\hline \multirow[b]{2}{*}{ Parameters } & \multirow[b]{2}{*}{ Units } & \multicolumn{2}{|c|}{ FW } & \multicolumn{2}{|c|}{ DSW } & \multicolumn{2}{|c|}{ MW } \\
\hline & & $\begin{array}{c}\text { Oct-2017 to } \\
\text { Sept-2018 }\end{array}$ & $\begin{array}{l}\text { Oct-2018 to } \\
\text { Jun-2019 }\end{array}$ & $\begin{array}{c}\text { Oct-2017 to } \\
\text { Sept-2018 }\end{array}$ & $\begin{array}{l}\text { Oct-2018 to } \\
\text { Jun-2019 }\end{array}$ & $\begin{array}{c}\text { Oct-2017 to } \\
\text { Sept-2018 }\end{array}$ & $\begin{array}{c}\text { Oct-2018 to } \\
\text { Jun-2019 }\end{array}$ \\
\hline $\mathrm{pH}$ & & $7.7 \pm 0.2$ & $7.8 \pm 0.1$ & $7.9 \pm 0.3$ & $7.9 \pm 0.8$ & $7.7 \pm 0.2$ & $7.8 \pm 0.1$ \\
\hline $\mathrm{EC}_{\mathrm{w}}$ & $\mathrm{dS} / \mathrm{m}$ & $1.7 \pm 0.4$ & $1.1 \pm 0.0$ & $0.9 \pm 0.0$ & $0.9 \pm 0.2$ & $1.4 \pm 0.2$ & $1.0 \pm 0.1$ \\
\hline $\mathrm{Ca}^{2+}$ & $\mathrm{mg} / \mathrm{L}$ & $65.1 \pm 12.9$ & $59.9 \pm 9.4$ & $24.3 \pm 6.5$ & $30.5 \pm 18.0$ & $45.2 \pm 8.9$ & $45.5 \pm 9.2$ \\
\hline $\mathrm{Mg}^{2+}$ & $\mathrm{mg} / \mathrm{L}$ & $44.4 \pm 12.3$ & $31.7 \pm 5.2$ & $9.1 \pm 2.1$ & $10.7 \pm 10.7$ & $27.9 \pm 5.8$ & $21.8 \pm 6.4$ \\
\hline $\mathrm{Na}^{+}$ & $\mathrm{mg} / \mathrm{L}$ & $195.1 \pm 72.7$ & $128.0 \pm 25.3$ & $152.6 \pm 19.1$ & $109.6 \pm 38.2$ & $175.9 \pm 37.2$ & $130.1 \pm 7.2$ \\
\hline $\mathrm{K}^{+}$ & $\mathrm{mg} / \mathrm{L}$ & $11.7 \pm 2.8$ & $7.2 \pm 1.6$ & $7.1 \pm 1.0$ & $5.9 \pm 2.9$ & $10.1 \pm 2.2$ & $6.4 \pm 1.1$ \\
\hline $\mathrm{B}^{3+}$ & $\mathrm{mg} / \mathrm{L}$ & $0.61 \pm 0.28$ & $0.49 \pm 0.07$ & $0.84 \pm 0.11$ & $0.85 \pm 0.19$ & $0.72 \pm 0.11$ & $0.71 \pm 0.09$ \\
\hline $\mathrm{Cl}^{-}$ & $\mathrm{mg} / \mathrm{L}$ & $298.2 \pm 114.8$ & $189.0 \pm 24.2$ & $244.5 \pm 37.7$ & $178.2 \pm 63.2$ & $266.6 \pm 65.2$ & $206.9 \pm 15.3$ \\
\hline $\mathrm{SO}_{4}^{2-}$ & $\mathrm{mg} / \mathrm{L}$ & $181.1 \pm 48.6$ & $159.5 \pm 34.2$ & $14.5 \pm 4.1$ & $34.6 \pm 53.4$ & $95.9 \pm 25.6$ & $98.9 \pm 28.9$ \\
\hline $\mathrm{NO}_{3}^{-}$ & $\mathrm{mg} / \mathrm{L}$ & $6.6 \pm 1.7$ & $8.7 \pm 2.8$ & $2.2 \pm 2.2$ & $4.3 \pm 4.6$ & $5.3 \pm 1.9$ & $4.9 \pm 1.5$ \\
\hline $\mathrm{PO}_{4}{ }^{3-}$ & $\mathrm{mg} / \mathrm{L}$ & $\mathrm{LD}^{*}<0.76$ & $\mathrm{LD}^{*}<0.76$ & $\mathrm{LD}^{*}<0.76$ & $\mathrm{LD}^{*}<0.76$ & $\mathrm{LD} *<0.76$ & $\mathrm{LD}^{*}<0.76$ \\
\hline $\mathrm{SAR}_{\mathrm{W}}$ & {$[\mathrm{mmol} / \mathrm{L}]^{0.5}$} & $4.5 \pm 1.4$ & $3.4 \pm 0.7$ & $6.8 \pm 0.8$ & $4.7 \pm 1.6$ & $5.1 \pm 0.9$ & $4.0 \pm 1.0$ \\
\hline \multicolumn{4}{|c|}{ Max threshold $\mathrm{Na}^{+}$} & \multicolumn{4}{|c|}{115 mg/L Grattan et al. [30] } \\
\hline \multicolumn{2}{|c|}{ Max threshold $\mathrm{Cl}^{-}$} & \multicolumn{6}{|c|}{$350 \mathrm{mg} / \mathrm{L}$ Hanson et al. [32]; 152-238 mg/L Grattan et al. [30] } \\
\hline \multicolumn{2}{|c|}{ Max threshold $\mathrm{B}^{3+}$} & \multicolumn{6}{|c|}{$0.5 \mathrm{mg} / \mathrm{L}$ Martínez-Alvarez et al. [4]; Voutchkov and Semiat [31] } \\
\hline
\end{tabular}

*: LD: below the detection limit.

The $\mathrm{EC}_{\mathrm{W}}$ of the DSW was $0.9 \mathrm{dS} / \mathrm{m}$ due to the large salt removal in the RO process. However, the high concentration of $\mathrm{Na}^{+}$and the low of $\mathrm{Ca}^{2+}$ and $\mathrm{Mg}^{2+}$ led to high $\mathrm{SAR}_{\mathrm{W}}$ values $(6.8 \pm 0.8$ $[\mathrm{mmol} / \mathrm{L}]^{0.5}$ ) from Oct-2017 to Sept-2018 and $4.7 \pm 1.6[\mathrm{mmol} / \mathrm{L}]^{0.5}$ from Oct-2018 to Jun-2019), compared to the FW (Table 1).

All the experimental treatments received the same amount of irrigation water $\left(1663 \mathrm{~m}^{3} / \mathrm{ha}\right.$ from Oct-2017 to Sept-2018 and $1025 \mathrm{~m}^{3} /$ ha from Oct-2018 to Jun-2019). 


\subsection{Soil Salinity and Sodicity}

Figure 1 shows the evolution of $\mathrm{EC}_{\mathrm{e}}$ and $\mathrm{SAR}_{\mathrm{e}}$ for each treatment from October 2017 to June 2019, for $0-25 \mathrm{~cm}$ and $25-50 \mathrm{~cm}$ depths (FW, DSW, and MW).
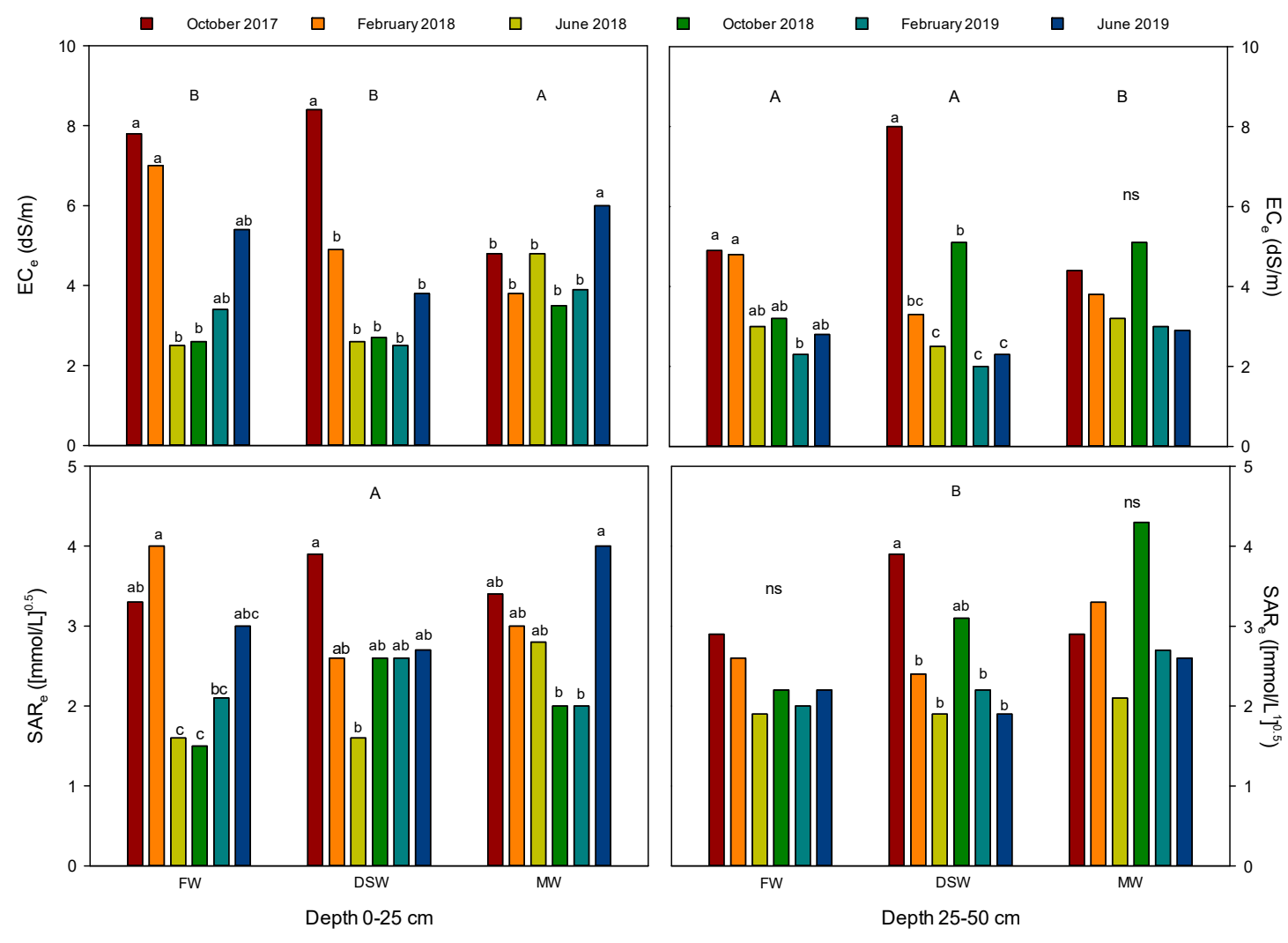

Figure 1. Electrical conductivity of the saturated paste extract $\left(\mathrm{EC}_{\mathrm{e}}, \mathrm{dS} / \mathrm{m}\right)$ and sodium adsorption ratio $\left(\mathrm{SAR}_{\mathrm{e}}\right.$ ) in the three irrigation treatments (fresh water, FW; desalinized sea water, DSW; and mix water, MW) from October 2017 to June 2019 for 0-25 cm and 25-50 cm depths. Values represent the mean for each sampling period ( $\mathrm{N}=3$ for each sampling). Similar small letters in each bar indicate no significant differences among samplings; no small letters means no significant differences; and different capital letters in each treatment for surface and depth samplings indicate significant differences between depths, in both cases according to Tukey's HSD test $(\mathrm{P} \leq 0.05)$.

First, the large initial variability of the $\mathrm{EC}_{\mathrm{e}}$ and $\mathrm{SAR}_{\mathrm{e}}$ among samples collected at different points of the orchard should be highlighted. For example, while $\mathrm{EC}_{\mathrm{e}}$ measured at $25 \mathrm{~cm}$ in the $\mathrm{FW}$ treatment in October 2017 was $7.8 \mathrm{dS} / \mathrm{m}$, it was $4.8 \mathrm{dS} / \mathrm{m}$ in the MW treatment. A similar situation was found with $\mathrm{SAR}_{\mathrm{e}}$, especially at the $50 \mathrm{~cm}$ depth initial sampling. Such a huge initial non-homogeneity could be explained by the initial soil conditioning performed to establish the orchard, mainly due to the creation of ridges and the addition of organic matter. After that date, these high $\mathrm{EC}_{\mathrm{e}}$ and $\mathrm{SAR}_{\mathrm{e}}$ values began to be lower due to the rain which fell between January and June 2018 (103.8 $\mathrm{mm})$. With salts having been leached from the soils, especially in FW and DSW treatments, new $\mathrm{EC}_{\mathrm{e}}$ and $\mathrm{SAR}_{\mathrm{e}}$ increases were again observed in June 2019.

Concerning the risk of soil sodicity, it is well known that high concentrations of $\mathrm{Na}^{+}$can damage the soil physical properties, causing clay dispersion which leads to: (i) the structural collapse of soil aggregates; (ii) decreased soil hydraulic conductivity; (iii) erosion problems; (iv) soil compaction; and (v) decreased soil aeration [11,33]. The results indicated that only irrigation with the DSW could induce a certain sodicity risk into the soil (Figure 2). As the DSW presented low $\mathrm{EC}_{\mathrm{W}}$, such sodicity risks could be corrected by adjusting the fertigation programs to increase the amount of $\mathrm{Ca}^{2+}$ and $\mathrm{Mg}^{2+}$ to displace $\mathrm{Na}^{+}$from the soil cation exchange complex, hence reducing the SAR $\mathrm{e}$ or blending the DSW 
with FW or other non-conventional water resources such as reclaimed or underground waters. In any case, seasonal soil monitoring is strongly encouraged to detect any deterioration of the soil structure when DSW is used alone for crop irrigation, especially in soils with a high clay content, where the sodicity hazard may be more relevant [4].

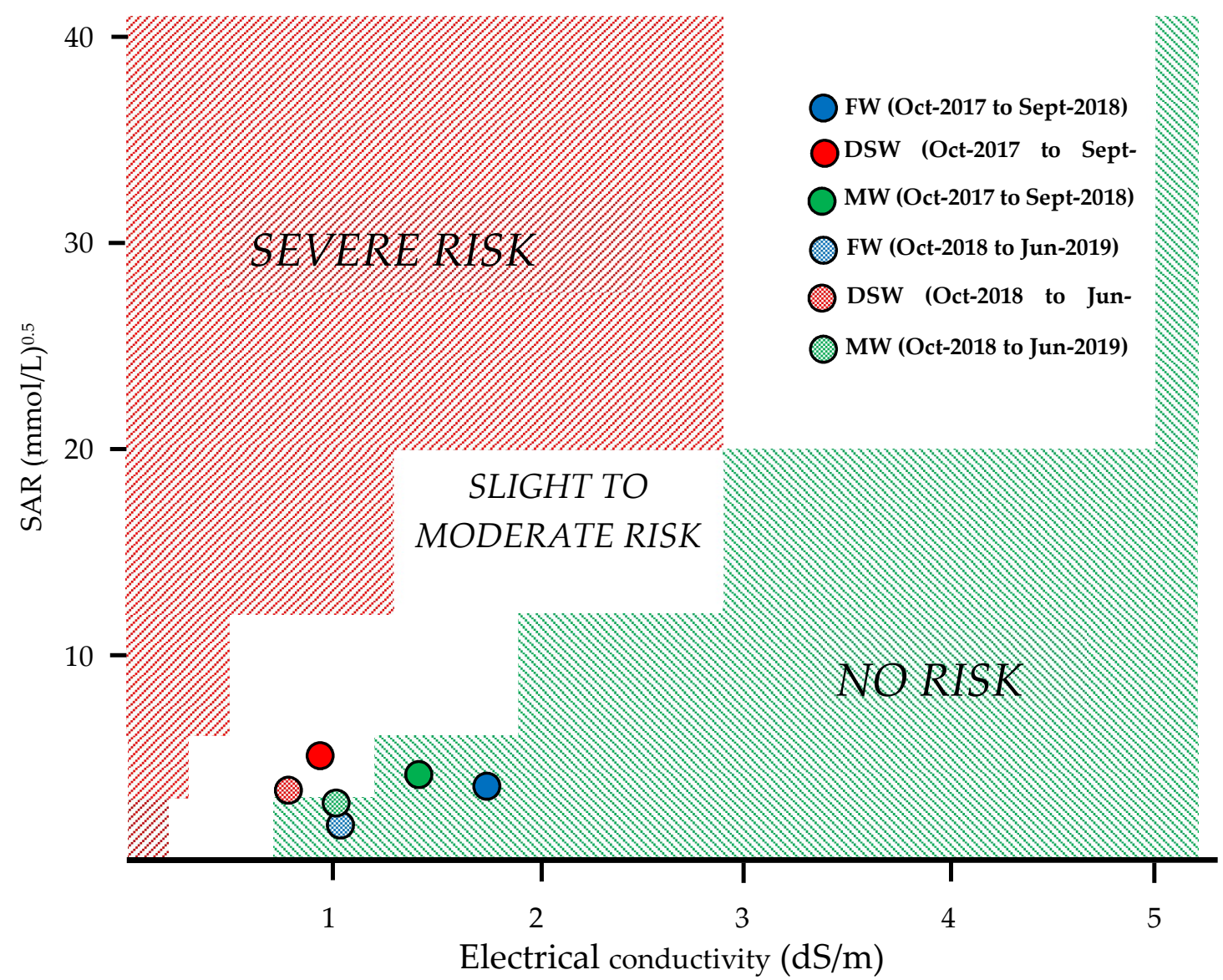

Figure 2. Soil sodicity potential risk evaluated using the sodium adsorption ratio $\left(\mathrm{SAR}_{\mathrm{W}}\right)$ and the electrical conductivity $\left(\mathrm{EC}_{\mathrm{W}}\right)$ of the irrigation water in the three irrigation treatments (fresh water; $\mathrm{FW}$, desalinized seawater; DSW, and mix water; MW).

\subsection{Leaf Mineral Analysis and Phytotoxic Elements}

Figure 3 shows the mean leaf concentrations of $\mathrm{Na}^{+}, \mathrm{Cl}^{-}$, and $\mathrm{B}^{3+}$ for the periods from October 2017 to September 2018 and from October 2018 to June 2019 for the three irrigation treatments.

During the two years of the experiment, concentrations of macro-and micro-nutrients $\left(\mathrm{N}, \mathrm{P}, \mathrm{K}^{+}\right.$, $\mathrm{Ca}^{2+}, \mathrm{Mg}^{2+}, \mathrm{Fe}, \mathrm{Mn}$, and $\mathrm{Zn}$ ) measured in the leaves were within the optimum ranges proposed by Legaz et al. [34] (data not shown).

Regarding the $\mathrm{Na}^{+}$measured in the citrus leaves, no significant differences were observed among treatments and no trends of $\mathrm{Na}^{+}$increases were maintained over time throughout the experiment. Although the concentration of $\mathrm{Na}^{+}$in most of the tested irrigation waters exceeded the toxic threshold proposed for citrus by Grattan et al. by more than 50\% [30] (115 mg/L; Table 1), almost all of the leaf samples were below the minimum threshold within the range for leaf phytotoxicity proposed by Grattan et al. [30] (Figure 3a). In any case, all values were found below the maximum $\mathrm{Na}^{+}$threshold proposed by Grattan et al. [30] for citrus $(2.5 \mathrm{~g} / \mathrm{kg})$. Moreover, the trees were well supplied with $\mathrm{K}^{+}$ (between 11 and $29 \mathrm{~g} / \mathrm{kg}$ of dry matter) and with $\mathrm{Ca}^{2+}$ (between 17 and $54 \mathrm{~g} / \mathrm{kg}$ of dry matter), which could have limited the $\mathrm{Na}^{+}$uptake by roots and its transport to the leaves $[35,36]$. 

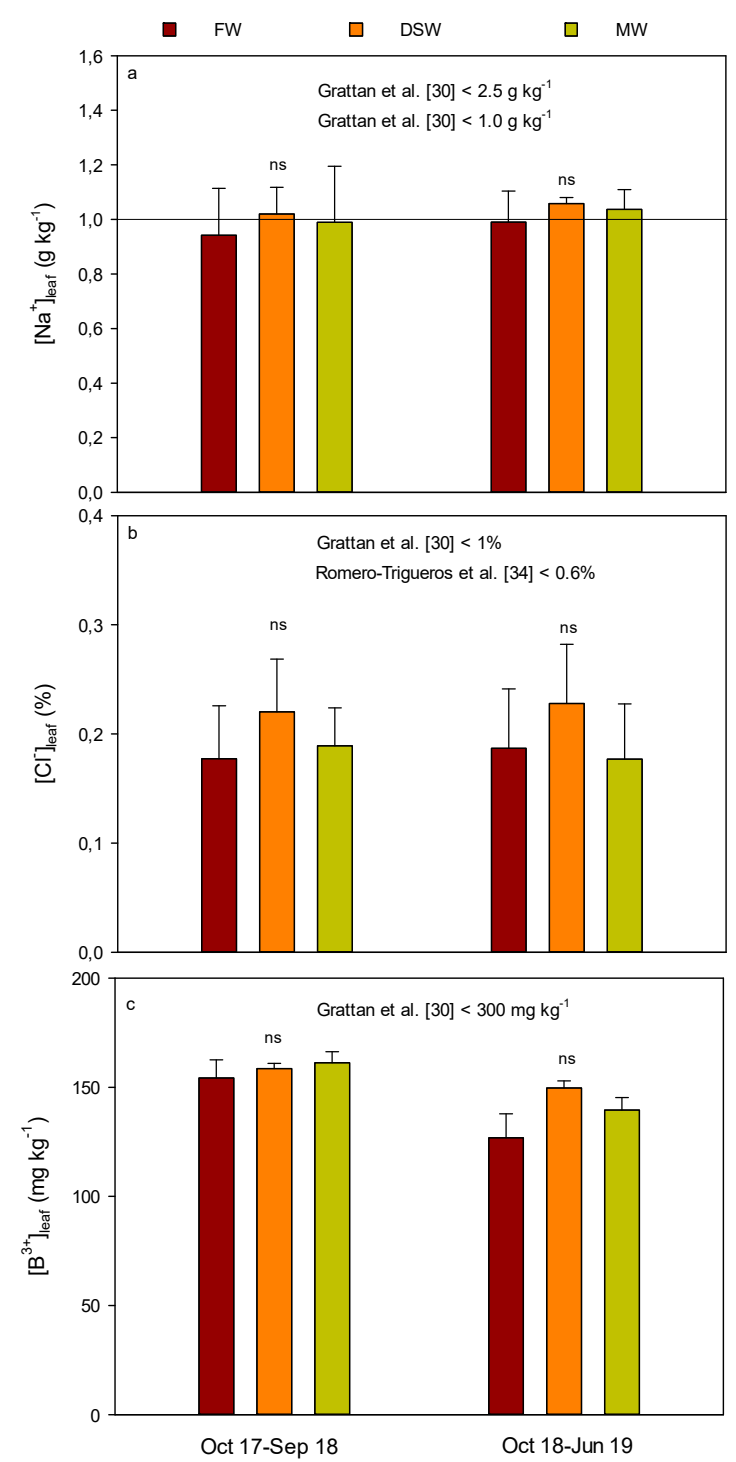

Figure 3. Mean leaf concentrations and standard deviations of $(\mathbf{a}) \mathrm{Na}^{+},(\mathbf{b}) \mathrm{Cl}^{-}$, and (c) $\mathrm{B}^{3+}$ for the periods from October 2017 to September 2018 and from October 2018 to June 2019 for the three irrigation treatments (fresh water; FW, desalinated sea water; DSW, and mixed water; MW). ns means that significant differences were not detected among the treatments for each period $(P \leq 0.05)$. References in the figures represent toxic thresholds found for citrus.

Regarding $\mathrm{Cl}^{-}$, only sporadic significant differences among treatments occurred during the summer months in 2018 (from April 2018 to September 2018; data not shown). As observed for $\mathrm{Na}^{+}$, no trends of $\mathrm{Cl}^{-}$increase in leaves were observed throughout the experiment (Figure $3 \mathrm{~b}$ ). The concentration of $\mathrm{Cl}^{-}$in the irrigation waters was well below the threshold proposed by Hanson et al. [31] $(350 \mathrm{mg} / \mathrm{L}$; Table 1) and never exceeded the leaf toxic threshold proposed by Romero-Trigueros et al. [37] and Grattan et al. [30]; i.e., 6 and $10 \mathrm{~g} / \mathrm{kg}$, respectively (Figure $3 \mathrm{~b}$ ).

The $\mathrm{B}^{3+}$ concentration in the irrigation waters exceed the maximum threshold proposed for citrus [4,31] (0.5 mg/L; Table 1). In this context, Abu-Daba'an and Al-Najar [38] irrigated a citrus orchard for ten consecutive years with a treated effluent with a $B^{3+}$ concentration of $1.03 \pm 0.45 \mathrm{mg} / \mathrm{L}$ and did not reach toxic levels for $\mathrm{B}^{3+}$ leaf concentration. However, they also concluded that, since $\mathrm{B}^{3+}$ is accumulative, if the same irrigation water is used for 30 years, leaf $\mathrm{B}^{3+}$ concentrations could reach that harmful level. In our short-term study, no trends of $\mathrm{B}^{3+}$ increase in leaves have been observed throughout the experiment. The critical leaf $\mathrm{B}^{3+}$ concentration in citrus when toxicity occurs falls in the 
250-260 mg/kg dry weight range [39], although $\mathrm{B}^{3+}$ can become toxic at higher tissue concentrations of $100 \mathrm{mg} / \mathrm{kg}$ dry weight, ranges of $100-300 \mathrm{mg} / \mathrm{kg}$ dry weight tend to produce slight to moderate injury [30]. Leaf $\mathrm{B}^{3+}$ concentrations in our study ranged between $100-200 \mathrm{mg} / \mathrm{kg}$ with no differences between the DSW-irrigated trees and the control ones (Figure 3c). No visual leaf injury was observed in the first two years of study. On the other hand, diverse research works indicate that the foliar concentration might not be the only factor that determines the relative tolerance of different rootstocks to boron $[40,41]$.

\subsection{Plant Water Status and Leaf Gas Exchange}

Figure 4 presents the average plant $\Psi_{\text {stem }}, \Psi_{\text {leaf }}, \Psi_{\text {osm }}$, and leaf turgor pressure measured from May 2018 to May 2019 for the three irrigation treatments.

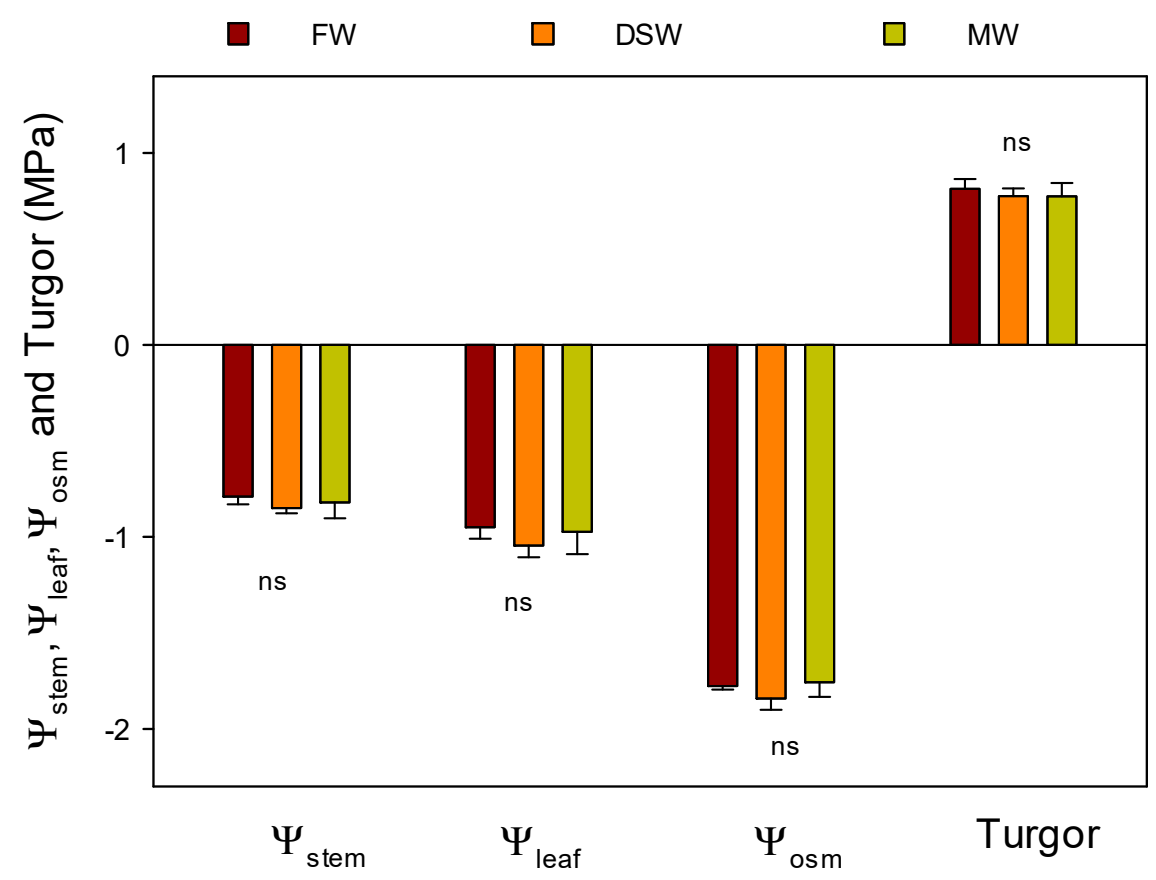

Figure 4. Mean plant water relations and standard deviations ( $\Psi_{\text {stem, }}$, stem water potential; $\Psi_{\text {leaf }}$, leaf water potential; $\Psi_{\mathrm{osm}}$, osmotic potential and leaf turgor pressure; expressed in MPa) measured from May 2018 to May 2019 for the three irrigation treatments (fresh water; FW, desalinated sea water; DSW, and mixed water; MW). ns means that significant differences were not detected among treatments for each period $(\mathrm{P} \leq 0.05)$.

The plant water relations, analyzed as $\Psi_{\text {stem }}, \Psi_{\text {leaf }}, \Psi_{\text {osm }}$, and leaf turgor, irrespective of the treatment, remained quite constant during the experiment, and their values indicated the good water status of the trees (Figure 4) [42-44]. In fact, significant differences between treatments were only observed in August 2019 (data not shown), and were associated to a high-water demand period. At this date, $\Psi_{\text {leaf }}$ and $\Psi_{\text {osm }}$ were significantly lower in the DSW with regard to both the FW and the MW treatments (data not shown) but not enough to induce differences in leaf turgor. In this sense, it has been demonstrated that citrus can reduce $\Psi_{\text {osm }}$, which allows to reduce $\Psi_{\text {leaf }}$ with no alteration of leaf turgor potential, thus avoiding leaf dehydration by leaf $\mathrm{Cl}^{-}$and $\mathrm{Na}^{+}$accumulation under saline environmental stress [45]. In our study, $\mathrm{Cl}^{-}$and $\mathrm{Na}^{+}$concentrations of DSW were similar to those found in the FW, so no $\mathrm{Na}^{+}$or $\mathrm{Cl}^{-}$accumulation could be produced to reduce osmotic potential (Figure 4). Instead of that, in August 2018 a significant increase of proline was produced in citrus leaves of DSW-irrigated trees with regard to those irrigated with the FW or MW (data not shown). To maintain plant turgor when a lowering of leaf water status occurs many plants may also enhance 
biosynthesis of secondary metabolites, such as some amino acids, which may act as osmolytes under these situations [46].

Regarding the crop gas exchange, no differences in $\mathrm{A}, \mathrm{g}_{\mathrm{s}}, \mathrm{E}, \mathrm{Ci}, \mathrm{A} / \mathrm{E}$, or $\mathrm{A} / \mathrm{g}_{\mathrm{s}}$ among treatments were observed throughout the experiment (Table 2). A and $g_{s}$ ranged between $3.19 \mu \mathrm{mol} / \mathrm{m}^{2} / \mathrm{s}$ and $0.027 \mathrm{mmol} / \mathrm{m}^{2} / \mathrm{s}$, observed in the DSW treatment in May 2019 and November 2018, respectively to $10.61 \mu \mathrm{mol} / \mathrm{m}^{2} / \mathrm{s}$ and $0.111 \mathrm{mmol} / \mathrm{m}^{2} / \mathrm{s}$, observed in the FW treatment in September 2018 . As expected, the highest values for $\mathrm{A}, \mathrm{E}$, and $\mathrm{g}_{\mathrm{s}}$ were registered in summer due to the increase in the evapotranspirative demand ruled by a significant increase in the vapor pressure deficit and solar radiation (data not shown) [44]. All these increases in the gas interchange parameters during the summer time were mainly due to a higher stomatal opening; however, they did not change in the same way and a seasonal variation in leaf water use efficiency was observed, as was previously reported by Medrano et al. [47]. The ratio of the fluxed of net photosynthesis and conductance for water vapor (A/E), which indicates the cost of $\mathrm{CO}_{2}$ assimilation per unit of water, decreased during the summer time, ranging from 6.9 to $2.8 \mu \mathrm{mol} \mathrm{CO} \mathrm{C} \mathrm{m}^{-2} \mathrm{~s}^{-1} / \mathrm{mmol} \mathrm{H}_{2} \mathrm{O} \mathrm{m}^{-2} \mathrm{~s}^{-1}$ in November 2018 and May 2019 respectively in the DSW treatment (data not shown). Similarly, intrinsic water-use efficiency $\left(\mathrm{A} / \mathrm{g}_{\mathrm{s}}\right)$ values ranged from 160 to $74 \mu \mathrm{mol} \mathrm{CO} \mathrm{m}^{-2} \mathrm{~s}^{-1} / \mathrm{mol} \mathrm{H}_{2} \mathrm{O} \mathrm{m}^{-2} \mathrm{~s}^{-1}$ in November 2018 and May 2019 respectively in the DSW treatment, showing the lower plant efficiency to fix $\mathrm{CO}_{2}$ per unit of $\mathrm{H}_{2} \mathrm{O}$ lost during the summertime. Both instantaneous and intrinsic water-use efficiency did not show significant differences for the three water quality treatments in their mean values recorded from May 2018 to May 2019 (Table 2). However, values recorded in May 2019 in the DSW for A/E and A/gs were significantly lower than those found in the FW and MW-irrigated trees (data not shown).

Table 2. Mean stomatal conductance $\left(\mathrm{g}_{\mathrm{s}}, \mathrm{mol} \mathrm{H}_{2} \mathrm{O} \mathrm{m}^{-2} \mathrm{~s}^{-1}\right)$, net photosynthesis $\left(\mathrm{A}, \mu \mathrm{mol} \mathrm{CO} \mathrm{C}^{-2}\right.$ $\left.\mathrm{s}^{-1}\right)$, transpiration rate $\left(\mathrm{E}, \mathrm{mmol} \mathrm{H}_{2} \mathrm{O} \mathrm{m}^{-2} \mathrm{~s}^{-1}\right)$, sub-stomatal $\mathrm{CO}_{2}$ concentrations $\left(\mathrm{Ci}, \mu \mathrm{mol} \mathrm{CO}_{2}\right)$, instantaneous water-use efficiency $\left(\mathrm{A} / \mathrm{E}, \mu \mathrm{mol} \mathrm{CO} \mathrm{Cm}^{-2} \mathrm{~s}^{-1} / \mathrm{mmol} \mathrm{H}_{2} \mathrm{O} \mathrm{m}^{-2} \mathrm{~s}^{-1}\right.$ ), intrinsic water-use efficiency $\left(\mathrm{A} / \mathrm{g}_{\mathrm{s}}, \mu \mathrm{mol} \mathrm{CO} \mathrm{m}^{-2} \mathrm{~s}^{-1} / \mathrm{mol} \mathrm{H}_{2} \mathrm{O} \mathrm{m}^{-2} \mathrm{~s}^{-1}\right)$ for the three water quality treatments (fresh water, FW; desalinated seawater, DSW; and mixed water, MW). Data represent the mean and the standard deviation of monthly values collected from May-2018 to May-2019. ns means non-significant differences between treatments according to Tukey's HSD test $(\mathrm{P} \leq 0.05)$.

\begin{tabular}{ccccc}
\hline Parameters & FW & DSW & MW & Significance \\
\hline $\mathrm{g}_{\mathrm{s}}$ & $0.069 \pm 0.006$ & $0.064 \pm 0.007$ & $0.071 \pm 0.012$ & $\mathrm{~ns}$ \\
$\mathrm{~A}$ & $6.80 \pm 0.32$ & $6.56 \pm 0.54$ & $7.18 \pm 0.82$ & $\mathrm{~ns}$ \\
$\mathrm{E}$ & $1.76 \pm 0.09$ & $1.69 \pm 0.12$ & $1.81 \pm 0.22$ & $\mathrm{~ns}$ \\
$\mathrm{C}_{\mathrm{i}}$ & $204 \pm 12$ & $199 \pm 11$ & $201 \pm 13$ & $\mathrm{~ns}$ \\
$\mathrm{~A} / \mathrm{E}$ & $4.23 \pm 0.07$ & $4.20 \pm 0.14$ & $4.31 \pm 0.13$ & $\mathrm{~ns}$ \\
$\mathrm{~A} / \mathrm{g}_{\mathrm{s}}$ & $105 \pm 7$ & $108 \pm 7$ & $107 \pm 9$ & $\mathrm{~ns}$ \\
\hline
\end{tabular}

\subsection{Yield and Fruit Quality}

Concerning the soil salinity effects on the mandarin yield, several thresholds from which yield reductions could be expected have been proposed in literature. For instance, Ayers and Westcot [48] proposed a maximum $\mathrm{EC}_{\mathrm{e}}$ value of $1.7 \mathrm{dS} / \mathrm{m}$ for citrus. More recently, Nicolás et al. [44] established a threshold of $2.21 \mathrm{dS} / \mathrm{m}$ for Citrus Clementina cv. Orogrande mandarins grafted on Carrizo citrange (Citrus sinensis [L.] Osb. $\times$ Poncirustrifoliata [L.]) rootstock. In our case, $\mathrm{EC}_{\mathrm{e}}$ measured at second harvest (February 2019) ranged from $2.0 \pm 0.3 \mathrm{dS} / \mathrm{m}$ observed in the DSW treatment at $50 \mathrm{~cm}$ depth to $3.9 \pm$ $1.8 \mathrm{dS} / \mathrm{m}$ observed in the MW treatment at $25 \mathrm{~cm}$ depth. Therefore, these figures might have provoked notable yield reductions. However, during the two-year experimental period, no significant differences among treatments were observed in the yield components or in the fruit quality. This circumstance could be mainly explained by the large standard deviations caused by the youth of the trees, which for some values, represented more than $100 \%$ of the mean; a clear example of this is the crop fruit load for the FW or DSW in February 2018 (Table 3). Significant differences in tree canopy equatorial area, 
crop load, yield, yield/tree canopy equatorial area, fruit weight, and fruit quality parameters were not observed in the February 2019 harvest either (Table 4). As occurred in the February 2018 harvest, a large data variance was observed and attributed to the young age of the trees.

Table 3. Tree canopy equatorial area, crop load, yield, yield/tree canopy equatorial, and fruit weight for the two experimental seasons and for the three irrigation treatments (fresh water, FW; desalinated seawater, DSW; and mixed water, MW). Each value is the average \pm standard deviation of the measurements performed in two inner trees per treatment (six central trees in each replicate per treatment). ns means non-significant differences between treatments according to Tukey's HSD test $(\mathrm{P} \leq 0.05)$.

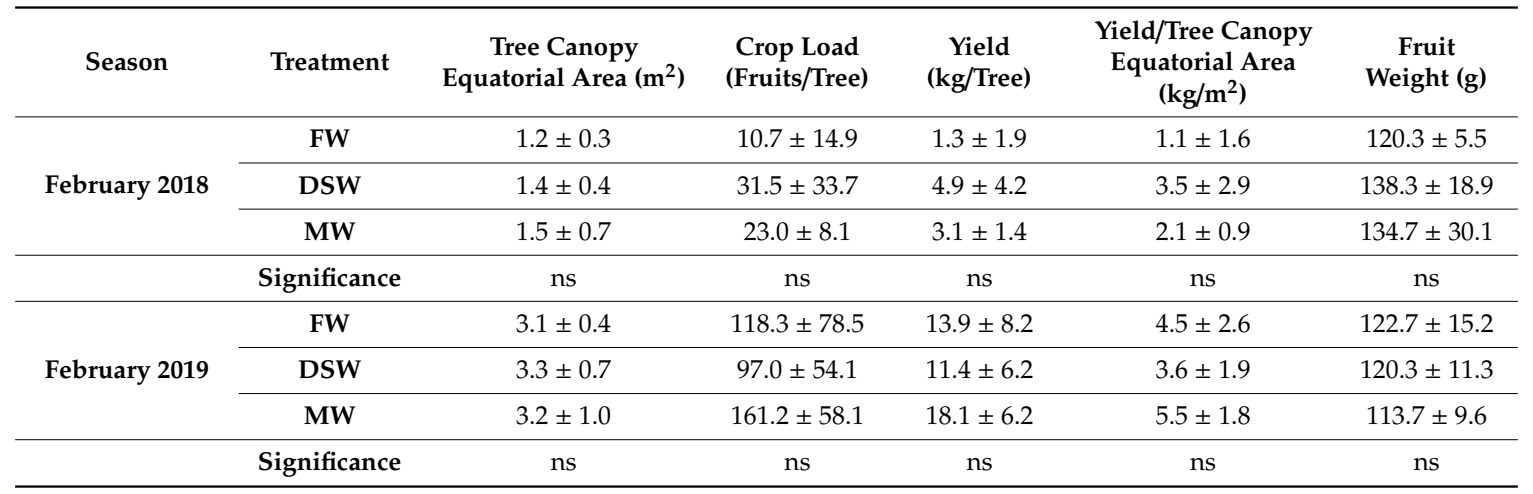

Table 4. Fruit quality parameters: equatorial and longitudinal diameters, juice and soluble solid content, peel thickness, titratable acidity, and maturity index for the two experimental seasons and for the three irrigation treatments (fresh water, FW; desalinated seawater, DSW; and mixed water, MW). ns means non-significant differences between treatments according to Tukey's HSD test $(\mathrm{P} \leq 0.05)$.

\begin{tabular}{|c|c|c|c|c|c|c|c|c|}
\hline Season & Treatment & $\begin{array}{c}\text { Equatorial } \\
\text { Diameter } \\
(\mathrm{mm})\end{array}$ & $\begin{array}{l}\text { Longitudinal } \\
\text { Diameter } \\
(\mathrm{mm})\end{array}$ & $\begin{array}{c}\text { Juice } \\
\text { Content } \\
(\%)\end{array}$ & $\begin{array}{c}\text { Soluble Solid } \\
\text { Content } \\
\left({ }^{\circ} \text { Brix }\right)\end{array}$ & $\begin{array}{c}\text { Peel } \\
\text { Thickness } \\
(\mathrm{mm})\end{array}$ & $\begin{array}{l}\text { Titratable } \\
\text { Acid (\%) }\end{array}$ & $\begin{array}{c}\text { Maturity } \\
\text { Index }\end{array}$ \\
\hline \multirow[t]{2}{*}{ February 2018} & DSW & - & - & $50.3 \pm 1.6$ & $12.4 \pm 0.8$ & - & - & - \\
\hline & MW & - & - & $51.1 \pm 2.2$ & $12.7 \pm 0.5$ & - & - & - \\
\hline \multirow[t]{3}{*}{ February 2019} & DSW & $66.0 \pm 2.2$ & $56.2 \pm 1.2$ & $45.3 \pm 1.64$ & $14.2 \pm 0.8$ & $3.0 \pm 0.2$ & $1.6 \pm 0.1$ & $9.0 \pm 0.8$ \\
\hline & Significance & $65.3 \pm 2.5$ & $56.8 \pm 2.4$ & $43.7 \pm 1.79$ & $14.0 \pm 0.9$ & $2.8 \pm 0.2$ & $1.5 \pm 0.3$ & $9.5 \pm 1.1$ \\
\hline & ANOVA & $\mathrm{ns}$ & $\mathrm{ns}$ & ns & ns & ns & ns & ns \\
\hline
\end{tabular}

Concerning the quality parameters, the measured juice content and soluble solid content agreed with the results previously published by Nicolás et al., Asharaf and Harris, and Navarro et al. $[44,46,49,50]$ on mandarin trees irrigated with fresh water in southeast Spain.

\subsection{Economic Assessment}

The irrigation with the DSW almost doubled the cost of the irrigation water (Table 5). In 2019, the income from selling the fruit was lower than the FW due to lower yields, although significant differences were not observed due to the large variability in yield, as commented in Section 3.5. income-outlay results shown in Table 5 for October 2018 to June 2019 indicated that the MW treatment was the most economically feasible due to the higher yield in proportion to the increase in the cost of water. Please note that significant differences among FW and DSW treatments were not detected. In addition, the large variability in yield must be taken into consideration. 
Table 5. Economic assessment of the mandarin production under the three scenarios selected. For each year and row, means with the same letter are not significantly different according to Tukey's HSD test $(\mathrm{P} \leq 0.05)$.

\begin{tabular}{ccccccc}
\hline Title & \multicolumn{3}{c}{ Oct-2017 to Sept-2018 } & \multicolumn{3}{c}{ Oct-2018 to Jun-2019 } \\
\hline $\mathbf{E} /$ ha & FW & DSW & MW & FW & DSW & MW \\
\hline Water cost & 582 & 998 & 790 & 543 & 931 & 737 \\
Fruit selling income & $270 \pm 394 \mathrm{a}$ & $1017 \pm 872 \mathrm{a}$ & $643 \pm 290 \mathrm{a}$ & $2885 \pm 1702 \mathrm{a}$ & $2366 \pm 1287 \mathrm{a}$ & $3757 \pm 1287 \mathrm{a}$ \\
Income-Outlay & $-312 \pm 187 \mathrm{a}$ & $19 \pm 126 \mathrm{a}$ & $-146 \pm 499 \mathrm{a}$ & $2342 \pm 1159 \mathrm{ab}$ & $1435 \pm 356 \mathrm{~b}$ & $3020 \pm 549 \mathrm{a}$ \\
\hline
\end{tabular}

FW: fresh water; DSW: desalinated seawater; MW: mixed water.

\section{Conclusions}

This study has evaluated the short-term response of young mandarin trees to irrigation with desalinated seawater (DSW). The young age of the trees has favored the increase in the variability of the results and therefore, no significant differences among treatments have been observed in (i) the plant water status; (ii) the net photosynthesis and the stomatal conductance; (iii) the leaf phytotoxicity, except for $\mathrm{Na}^{+}$and $\mathrm{B}^{+3}$ in summer months; (iv) the yield components; and (v) the fruit quality. Although $\mathrm{Na}^{+}$and $\mathrm{B}^{+3}$ concentrations in the irrigation waters, irrespective of the treatment, have exceeded the toxic threshold proposed for citrus in the scientific literature, the $\mathrm{Na}^{+}$concentration in the leaves has only exceeded this threshold in three months from April to June in 2018. To summarize, although the results presented herein may, to a certain extent, justify the agronomic and economic viability of the use of DSW to irrigate young trees in the short-term, studies which consider such effects in the mid-long term, when the variability of the yield data is notably reduced, are still needed.

Author Contributions: The article was written by J.F.M.-V., with the rest of the authors providing many valuable comments. All authors have contributed equally to the methodology implementation, data acquisition, data analysis, and derived conclusions. All authors have read and agreed to the published version of the manuscript.

Funding: This study was supported by the European Regional Development Fund (ERDF) and Ministerio de Ciencia, Innovación y Universidades-Agencia Estatal de Investigación (Grant numbers AGL2017-85857-C2-2-R and RTC-2017-6192-2).

Acknowledgments: The collaboration of Catedra Trasvase y sostenibilidad-Jose Manuel Claver is acknowledged. J.G.P.P. is recipient of a Ramón y Cajal Fellowship (RYC-2015-17726) from Spanish Ministry of Economy and Competitiveness, Spain.

Conflicts of Interest: The authors declare no conflict of interest.

\section{References}

1. Food and Agriculture Organization of the United Nations (FAO). The Future of Food and Agriculture-Trends and Challenges; FAO: Rome, Italy, 2017.

2. Faures, J.M.; Bartley, D.; Bazza, M.; Burke, J.; Hoogeveen, J.; Soto, D.; Steduto, P. Climate Smart Agriculture Sourcebook; FAO: Rome, Italy, 2013; 557p.

3. Confederación Hidrográfica de la Cuenca del Segura. Plan Hidrológico de la Cuenca del Segura 2015-2021; CHS: Murcia, Spain, 2015. (In Spanish)

4. Martínez-Alvarez, V.; González-Ortega, M.J.; Martin-Gorriz, B.; Soto-García, M.; Maestre-Valero, J.F. The use of desalinated seawater for crop irrigation in the Segura River Basin (south-eastern Spain). Desalination 2017, 422, 153-164. [CrossRef]

5. Martínez-Alvarez, V.; Maestre-Valero, J.F.; González-Ortega, M.J.; Gallego-Elvira, B.; Martin Gorriz, B. Characterization of the Agricultural Supply of Desalinated Seawater in Southeastern Spain. Water 2019, 11, 1233. [CrossRef]

6. Raveh, E.; Ben-Gal, A. Leveraging Sustainable Irrigated Agriculture via Desalination: Evidence from a Macro-Data Case Study in Israel. Sustainability 2018, 10, 974. [CrossRef]

7. Bates, B.; Kundzewicz, Z.W.; Wu, S.; Palutikof, J. (Eds.) Climate Change and Water, Technical Paper of the Intergovernmental Panel on Climate Change; IPCC Secretariat: Geneva, Switzerland, 2008. 
8. Aznar-Sánchez, J.A.; Belmonte-Ureña, L.J.; Valera, D.L. Perceptions and Acceptance of Desalinated Seawater for Irrigation: A Case Study in the Nijar District (Southeast Spain). Water 2017, 9, 408. [CrossRef]

9. Ben-Gal, A.; Yermiyahu, U.; Cohen, S. Fertilization and blending alternatives for irrigation with desalinated water. J. Environ. Qual. 2009, 38, 529-536. [CrossRef] [PubMed]

10. Hilal, N.; Kim, G.J.; Somerfield, C. Boron removal from saline water: A comprehensive review. Desalination 2011, 273, 23-35. [CrossRef]

11. Mandal, U.K.; Bhardwaj, A.K.; Warrington, D.N.; Goldstein, D.; Tal, A.B.; Levy, G.J. Changes in soil hydraulic conductivity, runoff, and soil loss due to irrigation with different types of saline-sodic water. Geoderma 2008, 144, 509-516. [CrossRef]

12. Shaffer, D.L.; Yip, N.Y.; Gilron, J.; Elimelech, M. Seawater desalination for agriculture by integrated forward and reverse osmosis: Improved product water quality for potentially less energy. J. Membr. Sci. 2012, 415-416, 1-8. [CrossRef]

13. Martin-Gorriz, B.; Soto-García, M.; Martínez-Alvarez, V. Energy and greenhouse-gas emissions in irrigated agriculture of SE (southeast) Spain. Effects of alternative water supply scenarios. Energy 2014, 77, 478-488. [CrossRef]

14. Palomar, P.; Losada, I.J. Desalination in Spain: Recent developments and recommendations. Desalination 2010, 255, 97-106. [CrossRef]

15. Maestre-Valero, J.F.; Martin-Gorriz, B.; Soto-Garcia, M.; Martínez-Mate, M.A.; Martinez-Alvarez, V. Producing lettuce in soil-based or in soilless outdoor systems. Which is more economically profitable? Agric. Water Manag. 2018, 206, 48-55. [CrossRef]

16. Martínez-Alvarez, V.; Martin-Gorriz, B.; Soto-García, M. Seawater desalination for crop irrigation-A review of current experiences and revealed key issues. Desalination 2016, 381, 58-70. [CrossRef]

17. Allen, R.G.; Pereira, L.S.; Raes, D.; Smith, M. Crop Evapotranspiration Guidelines for Computing Crop Water Requirements; FAO Irrigation and Drainage Paper No. 56; FAO: Rome, Italy, 1998; pp. 15-27.

18. Castel, J.R.; Bautista, I.; Ramos, C.; Cruz, G. Evapotranspiration and irrigation efficiency of mature orange orchards in Valencia (Spain). Irrig. Drain. Syst. 1987, 3, 205-217. [CrossRef]

19. Fereres, E.; Castel, J.R. Drip Irrigation Management. Division of Agricultural Sciences; Leatlet 21259; University of California: Oakland, CA, USA, 1981.

20. Rhoades, J.D. Soluble salts. In Methods of Soil Analysis Part 2, Chemical and Microbiological Properties; Page, A.L., Miller, R.H., Kenney, D.R., Eds.; Agronomy Monograph; Soil Science Society of America: Madison, WI, USA, 1982; Volume 9, pp. 167-178.

21. Turner, N.C. Measurements of plant water status by pressure chamber technique. Irrig. Sci. 1988, 9, $289-308$. [CrossRef]

22. McCutchan, H.; Shackel, K.A. Stem-water potential as a sensitive indicator of water stress in prune trees (Prunus domestica L. cv French). J. Am. Soc. Hortic. Sci. 1992, 117, 607-611. [CrossRef]

23. Duchaufour, P.H. Precis de Pedologie; Masson: Paris, France, 1970; pp. 257-280.

24. Bates, L.S.M.; Waldren, R.P.; Teare, I.D. Rapid determination of free proline for water stress studies. Plant Soil 1973, 39, 205-207. [CrossRef]

25. Torrecillas, A.; León, A.; del Amor, F.; Martínez-Mompeán, M.C. Determinación rápida de clorofila en discos foliares de limonero. Fruits 1984, 39, 617-622. (In Spanish)

26. Sinclair, T.R.; Allen, L.H. Carbon dioxide and water vapour exchange of leaves on field-grown citrus trees. J. Exp. Bot. 1982, 33, 1166-1175. [CrossRef]

27. Syvertsen, J.P. Light acclimation in citrus leaves. II. $\mathrm{CO}_{2}$ assimilation and light, water and nitrogen use efficiency. J. Am. Soc. Hortic. Sci. 1984, 109, 812-817.

28. von Caemmerer, S.; Farquhar, G.D. Some relationships between the biochemistry of photosynthesis and the gas exchange of leaves. Planta 1981, 153, 376-387. [CrossRef]

29. Yermiyahu, U.; Tal, A.; Ben-Gal, A.; Bar-Tal, A.; Tarchitzky, J.; Lahav, O. Rethinking desalinated water quality and agriculture. Science 2007, 318, 920-921. [CrossRef] [PubMed]

30. Grattan, S.R.; Diaz, F.J.; Pedrero, F.; Vivaldi, G.A. Assessing the suitability of saline wastewaters for irrigation of Citrus spp.: Emphasis on boron and specific-ion interactions. Agric. Water Manag. 2015, 157, 48-58. [CrossRef] 
31. Voutchkov, N.; Semiat, R. Chapter 3. Seawater Desalination. In Advanced Membrane Technology and Applications, 1st ed.; Li, N.N., Fane, A.G., Ho, W.W., Matsuura, T., Eds.; John Wiley \& Sons, Inc.: Hoboken, NJ, USA, 2008; pp. 47-86.

32. Hanson, B.; Grattan, S.; Fulton, A. Agricultural Salinity and Drainage; Water Management Series Publication; University of California: Davis, CA, USA, 2006; Volume 3375, 157p.

33. Muyen, Z.; Moore, G.A.; Wrigley, R.J. Soil salinity and sodicity effects of wastewater irrigation in South East Australia. Agric. Water Manag. 2011, 99, 33-41. [CrossRef]

34. Legaz, F.; Serna, M.D.; Ferrer, P.; Cebolla, V.; Primo-Millo, E. Análisis de Hojas, Suelos y Aguas Para el Diagnóstico Nutricional de Plantaciones de Cítricos. Procedimiento de Toma de Muestras; Generalitat Valenciana: Valencia, Spain, 1995; Volume 27. (In Spanish)

35. Rubio, F.; Flores, P.; Navarro, J.M.; Martínez, V. Effects of $\mathrm{Ca}^{2+}, \mathrm{K}^{+}$and cGMP on $\mathrm{Na}^{+}$uptake in pepper plants. Plant Sci. 2003, 165, 1043-1049. [CrossRef]

36. Grieve, C.M.; Grattan, S.R.; Maas, E.V. Plant salt tolerance. In Agricultural Salinity Assessment and Management, 2nd ed.; Wallender, W.W., Tanji, K.K., Eds.; ASCE Manuals and Reports on Engineering Practice No. 71; American Society of Civil Engineers (ASCE): Reston, VA, USA, 2012; pp. 405-459.

37. Romero-Trigueros, C.; Nortes, P.A.; Pedrero, F.; Mounzer, O.; Alarcón, J.J.; Bayona, J.M.; Nicolás, E. Assessment of the viability of using saline reclaimed water in grapefruit in medium to long term. Span. J. Agric. Res. 2014, 12, 1137-1148. [CrossRef]

38. Abu-Daba'an, R.; Al-Najar, H. The Effect of Long Term Irrigation by Treated Effluent on Boron Accumulation in Soil and Citrus Plants. Asian Rev. Environ. Earth Sci. 2018, 5, 22-26. [CrossRef]

39. Embleton, T.W.; Jones, W.W.; Labanauskas, C.K.; Reuther, W. Leaf analysis as a diagnostic tool and guide to fertilization. In The Citrus Industry; Reuther, W., Ed.; University of California: Berkely, CA, USA, 1973; Volume 3, pp. 183-210.

40. Gimeno, V.; Simon, I.; Nieves, M.; Martinez, V.; Camara-Zapata, J.M.; Garcia, A.L.; García-Sánchez, F. The physiological and nutritional responses to an excess of boron by Verna lemon trees that were grafted on four contrasting rootstocks. Trees 2012, 26, 1513-1526. [CrossRef]

41. Mesquita, G.L.; Zambrosi, F.C.B.; Tanaka, F.A.O.; Boaretto, R.M.; Quaggio, J.A.; Ribeiro, R.V.; Mattos, D., Jr. Anatomical and physiological responses of citrus trees to varying boron availability are dependent on rootstock. Front. Plant Sci. 2016, 7, 224. [CrossRef]

42. Pérez-Pérez, J.G.; Romero, P.; Navarro, J.M.; Botía, P. Response of sweet orange cv 'Lane late' to deficit irrigation in two rootstocks. I: Water relations, leaf gas exchange and vegetative growth. Irrig. Sci. 2008, 26, 519-529. [CrossRef]

43. Pedrero, F.; Maestre-Valero, J.F.; Mounzer, O.; Nortes, P.A.; Alcobendas, R.; Romero-Trigueros, R.; Bayona, J.M.; Alarcón, J.J.; Nicolás, E. Response of young 'Star Ruby' grapefruit trees to regulated deficit irrigation with saline reclaimed water. Agric. Water Manag. 2015, 158, 51-60. [CrossRef]

44. Nicolás, E.; Alarcón, J.J.; Mounzer, O.; Pedrero, F.; Nortes, P.A.; Alcobendas, R.; Romero-Trigueros, C.; Bayona, J.M.; Maestre-Valero, J.F. Long-term physiological and agronomic responses of mandarin trees to irrigation with saline reclaimed water. Agric. Water Manag. 2016, 166, 1-8. [CrossRef]

45. Pérez-Pérez, J.G.; Syvertsen, J.P.; Botía, P.; García-Sánchez, F. Leaf water relations and net gas exchange responses of salinized Carrizo citrange seedlings during drought stress and recovery. Ann. Bot. 2007, 100, 335-345. [CrossRef] [PubMed]

46. Ashraf, M.; Harris, P.J.C. Potential Biochemical Indicators of Salinity Tolerance in Plants. Plant Sci. 2004, 166, 3-16. [CrossRef]

47. Medrano, H.; Tomás, M.; Martorell, S.; Flexas, J.; Hernández, E.; Roselló, J.; Pou, A.; Escalona, J.M.; Bota, J. From leaf to whole-plant water use efficiency (WUE) in complex canopies: Limitations of leaf WUE as a selection target. Crop J. 2015, 3, 220-228. [CrossRef]

48. Ayers, R.S.; Westcot, D.W. Water Quality for Agriculture; FAO Irrigation and Drainage Paper 29; Food and Agriculture Organization of the United Nations: Rome, Italy, 1985. 
49. Navarro, J.M.; Pérez-Pérez, J.G.; Romero, P.; Botía, P. Analysis of the changes in quality in mandarin fruit, produced by deficit irrigation treatments. Food Chem. 2010, 119, 1591-1596. [CrossRef]

50. Navarro, J.M.; Gómez-Gómez, A.; Pérez-Pérez, J.G.; Botía, P. Effect of saline conditions on the maturation process of Clementine Clemenules fruits on two different rootstocks. Span. J. Agric. Res. 2010, 8, S21-S29. [CrossRef] 